\title{
Comparative anatomy and histochemistry of the leaf blade of two species of Artocarpus
}

\author{
RAFAELA D. SÁ ${ }^{1}$, MARÍLIA B. CADENA ${ }^{1}$, RAFAEL J.R. PADILHA ${ }^{2}$, \\ LUIZ CARLOS ALVES ${ }^{2}$ and KARINA P. RANDAU ${ }^{1}$

\begin{abstract}
${ }^{1}$ Laboratório de Farmacognosia, Departamento de Ciências Farmacêuticas, Universidade Federal de Pernambuco, Av. Prof. Arthur de Sá, s/n, Cidade Universitária, 50740-521 Recife, PE, Brazil Pernambuco, Av. Professor Moraes Rego, s/n, Cidade Universitária, 50670-901 Recife, PE, Brazil
\end{abstract} \\ ${ }^{2}$ Setor de Microscopia Eletrônica, Laboratório de Imunopatologia Keizo Asami, Universidade Federal de
}

Manuscript received on November 13, 2017; accepted for publication on April 30, 2018

\begin{abstract}
How to cite: SÁ RD, CADENA MB, PADILHA RJR, ALVES LC AND RANDAU KP. 2019. Comparative anatomy and histochemistry of the leaf blade of two species of Artocarpus. An Acad Bras Cienc 91: e20170922. DOI 10.1590/0001-3765201820170922.
\end{abstract}

\begin{abstract}
In Brazil, there are two species of Artocarpus that were introduced: Artocarpus altilis (Parkinson) Fosberg, known as fruta-pão, and Artocarpus heterophyllus Lam., known as jaca. Both are used as food and medicine. The objective of this work was to conduct a comparative anatomical and histochemical study between A. altilis and A. heterophyllus. Techniques of optical, polarized and scanning electron coupled to energy dispersive spectroscopy. The anatomical characterization showed the characters of general occurrence in the family Moraceae and of those that allow the differentiation of A. altilis and A. heterophyllus. The histochemistry revealed the sites of synthesis and/or storage of the metabolites. The chemical microanalyses brought new information about the chemical composition of crystals. The study provides pharmacobotanical data for the quality control of the species.
\end{abstract}

Key words: Artocarpus altilis, Artocarpus heterophyllus, crystals, microscopy, Moraceae.

\section{INTRODUCTION}

The Moraceae family comprises 40 genera and about 1.217 species of occurrence in the tropical regions of the planet (The Plant List 2013), being that about $50 \%$ of the genera are distributed between the region of Mexico to Argentina (Berg 2001). In Brazil, the family is represented by 19 genera and 208 species (Romaniuc Neto et al. 2015), which have an important medicinal and economic value, known to present bioactive secondary metabolites

Correspondence to: Karina Perrelli Randau

E-mail: krandau@hotmail.com

ORCid: http://orcid.org/0000-0002-4486-4420 and to be exploited by the wood industry (Royer et al. 2010, Lima et al. 2011).

The genus Artocarpus comprises 61 species native to Asia and India, known for their much appreciated fruits (Ragone 2011, Stevens 2012). In Brazil, two species were introduced: Artocarpus altilis (Parkinson) Fosberg, known as frutapão, and Artocarpus heterophyllus Lam., known as jaca (Falcão et al. 2001, Pereira and Kaplan 2013). Worldwide, these two species are known, respectively, as breadfruit and jackfruit (Pereira and Kaplan 2013).

Both are perennial trees that produce latex, very cultivated in domestic orchards in the tropical regions 
of Brazil. The fruits are consumed in natura, baked or cooked, or in the form of candies and compotes (Lorenzi et al. 2015). Different parts of the plants are also used in traditional medicine to treat injuries, furuncles, back pain, rheumatisms and respiratory problems (Rodrigues 2006, Albuquerque et al. 2007, Agra et al. 2008, Aguiar and Barros 2012).

Studies with extracts, fractions and isolated components of the leaves of the two species demonstrate cardio-protective functions (Nwokocha et al. 2017), dendrite elongation inhibition (Rao et al. 2013), prevent atherosclerosis (Mozef et al. 2015) and have antiviral (Hafid et al. 2017), hypoglycemic and hypolipidemic effects (Chandrika et al. 2006, Chackrewarthy et al. 2010).

In addition to being widely used by the population as a therapeutic resource, these plant drugs can constitute raw materials used in the manufacture of phytotherapic. In some cases, medicinal plants may be erroneously used for presenting morphological similarities. Anatomical and histochemical studies contribute to the correct identification of these species (Brasil 2010). Thus, the objective of this work was to conduct a comparative study between $A$. altilis and $A$. heterophyllus to determine the authenticity parameters for these species.

\section{MATERIALS AND METHODS}

\section{PLANT MATERIAL}

Adult leaves of specimens of Artocarpus altilis and Artocarpus heterophyllus were collected in the neighborhood of Aldeia, Camaragibe, Pernambuco, Brazil. A voucher specimen was deposited in the Herbarium Dárdano de Andrade Lima of the Instituto Agronômico de Pernambuco (IPA), under registration number 91180 for A. altilis and 91181 for A. heterophyllus.
ANATOMICAL CHARACTERIZATION - OPTICAL MICROSCOPY

Various cross-sections were obtained by hand, using a common razor blade, in the middle region of leaf blades fixed in FAA 50\% (Johansen 1940). Paradermal sections were also performed on the adaxial and abaxial faces. All sections were subjected to decolorization with sodium hypochlorite solution (50\%) (Kraus and Arduin 1997), followed by washing with distilled water. Subsequently, the cross-sections were stained with safranin and astra blue (Bukatsch 1972) and paradermal sections were stained with methylene blue (1\%) (Krauter 1985). Then, semipermanent histological slides were prepared to contain the sections of botanical material, following common plant anatomy procedures (Johansen 1940, Sass 1951). The analysis of the semipermanent histological slides were conducted on images in software (LAS EZ), obtained by a digital camera (LEICA ICC50 W) coupled to an optical microscope (Leica DM750M).

\section{ANATOMICAL CHARACTERIZATION - POLARIZED LIGHT MICROSCOPY}

Semipermanent histological slides were prepared with cross-sections of leaf blades obtained by the same method used for the analysis in optical microscopy. For the analysis of the slides was used a polarized microscope (Leica DM750M) coupled with a digital camera (LEICA ICC50 W). The images were processed in software (LAS EZ).

\section{HISTOCHEMICAL CHARACTERIZATION}

Histochemical tests were made on cross-sections of fresh leaf blades obtained by hand, using a common razor blade (Johansen 1940). The specific reagents used were: potassium dichromate (10\%) for phenolic compounds (Gabe 1968); vanillin chloridric for tannins (Mace and Howell 1974); antimony trichloride for triterpenes and steroids 
(Mace et al. 1974); Dragendorff's reagent for detecting alkaloids (Yoder and Mahlberg 1976); Sudan III for lipophilic substances (Sass 1951); phloroglucinol for lignin (Johansen 1940); Lugol for starch (Johansen 1940) and hydrochloric acid $(10 \%)$ to establish the nature of the crystals (Jensen 1962). Controls were performed in parallel with the tests. Semipermanent histological slides were prepared to contain the cross-sections and were analyzed with an optical microscope (Leica DM750M) (Johansen 1940, Sass 1951).

\section{ANALYSIS OF THE ELEMENTAL COMPOSITION OF CRYSTALS}

Samples of fresh leaf blades were fixed in $2.5 \%$ glutaraldehyde (buffered with 4\% formaldehyde). After dehydration in ethanol series, the material was submitted to critical point drying (Hitachi HCP2) and mounted onto stubs, using double-sided adhesive tape and sputter-coated with gold (Q150T) (Haddad et al. 1998). Finally, the samples were examined with a Scanning Electron Microscope (SEM) (Zeiss EVO LS15). The chemical microanalyses by Energy Dispersive Spectroscopy (EDS) were done with an X-ray detector attached to the scanning electron microscope.

\section{RESULTS}

The leaf blade of $A$. altilis, in frontal view in optical microscopy, has cells with straight or slightly sinuous walls on both sides (Figure 1a, b). The leaf blade is hypoestomatic, with anomocytic and actinocytic stomata on the abaxial face (Figure 1b). The presence of druses is observed under optical and polarized microscopy on both faces of the leaf blade (Figure 1a-d). There are nonglandular trichomes and glandular trichomes. The non-glandular trichomes can be of three types: simple (Figure 1e), hooked (Figure 1f, g) and conical (Figure 1h, j). The glandular trichomes are multicellular and have eight or more cells (Figure
$1 \mathrm{i}, \mathrm{j})$. All types of trichomes described are found on both sides of the leaf blade, except for the simple non-glandular trichome, which is present only on the adaxial side.

The leaf blade of A. heterophyllus, in frontal view in optical microscopy, has cells of sinuous walls on both sides (Figure 2a, b). As it was visualized in $A$. altilis, the leaf blade of $A$. heterophyllus is hypoestomatic, with anomocytic and actinocytic stomata on the abaxial face (Figure 2b), and also presents druses on both faces, observed under optical and polarized microscopy (Figure 2a-d). In $A$. heterophyllus there is only one type of nonglandular trichome, the unicellular conical, and it is restricted to the abaxial face (Figure 2e). The glandular trichomes are multicellular, found on both sides of the leaf blade and have 6 or more cells (Figure 2f, g).

In cross-section, analyzed by scanning electron microscopy, the midrib of $A$. altilis shows a biconvex shape (Figure 3a) and A. heterophyllus shows midrib ranging from plane-convex to slightly biconvex (Figure 3b). Under optical microscopy, the epidermis on both species is uniseriate, covered with thin cuticle (Figure 3c, d). In both species there are lithocysts mainly in the regions of ribs (Figure $3 e, f)$. Two to four layers of collenchyma are situated below the epidermis in A. altilis (Figure 3c), while in A. heterophyllus the collenchyma is composed of three to seven layers of cells (Figure 3d).

The two species studied have a collateral vascular bundle in the midrib, associated with sclerenchyma (Figure 3c, d). Artocarpus heterophyllus presents a more developed medullar region of parenchyma than A. altilis (Figure 3c, d) and has idioblasts in the parenchyma (Figure 3d). Druses are observed in optical and polarized microscopy in the parenchyma and phloem of the two species (Figure 3c, d, g, h).

The mesophyll of both species, in crosssection visualized in optical microscopy, is dorsiventral, consisting of one to two layers of 


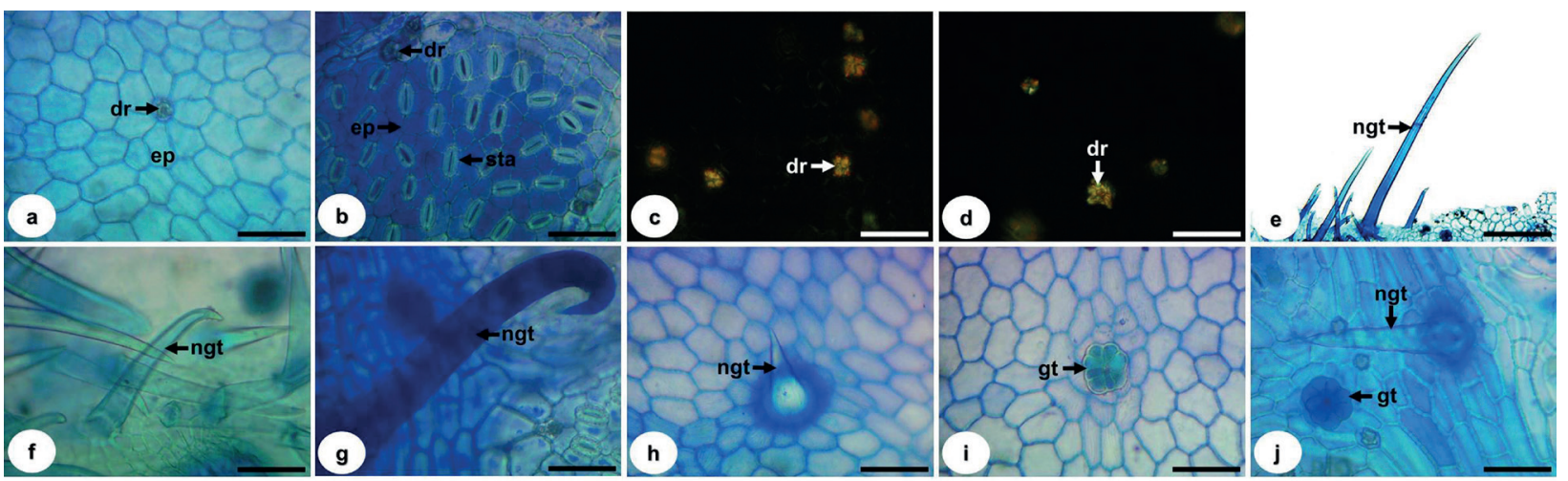

Figure 1 - Paradermal sections of the leaf blade of Artocarpus altilis. $\mathbf{a}, \mathbf{b}, \mathbf{e}, \mathbf{f}, \mathbf{g}, \mathbf{h}, \mathbf{i}$ and $\mathbf{j}$ : optical microscopy; $\mathbf{c}$ and $\mathbf{d}$ : polarized light microscopy; a, c, e, f, h and $\mathbf{i}$ : adaxial face; $\mathbf{b}, \mathbf{d}, \mathbf{g}$ and $\mathbf{j}$ : abaxial face. Abbreviations: dr = druse; ep = epidermis; gt = glandular trichome; ngt = non-glandular trichome; sta = stomata. Bars: $\mathbf{a}, \mathbf{b}, \mathbf{e}, \mathbf{f}, \mathbf{g}, \mathbf{h}, \mathbf{i}$ and $\mathbf{j}=50 \mu \mathrm{m} ; \mathbf{c}$ and $\mathbf{d}=20 \mu \mathrm{m}$.
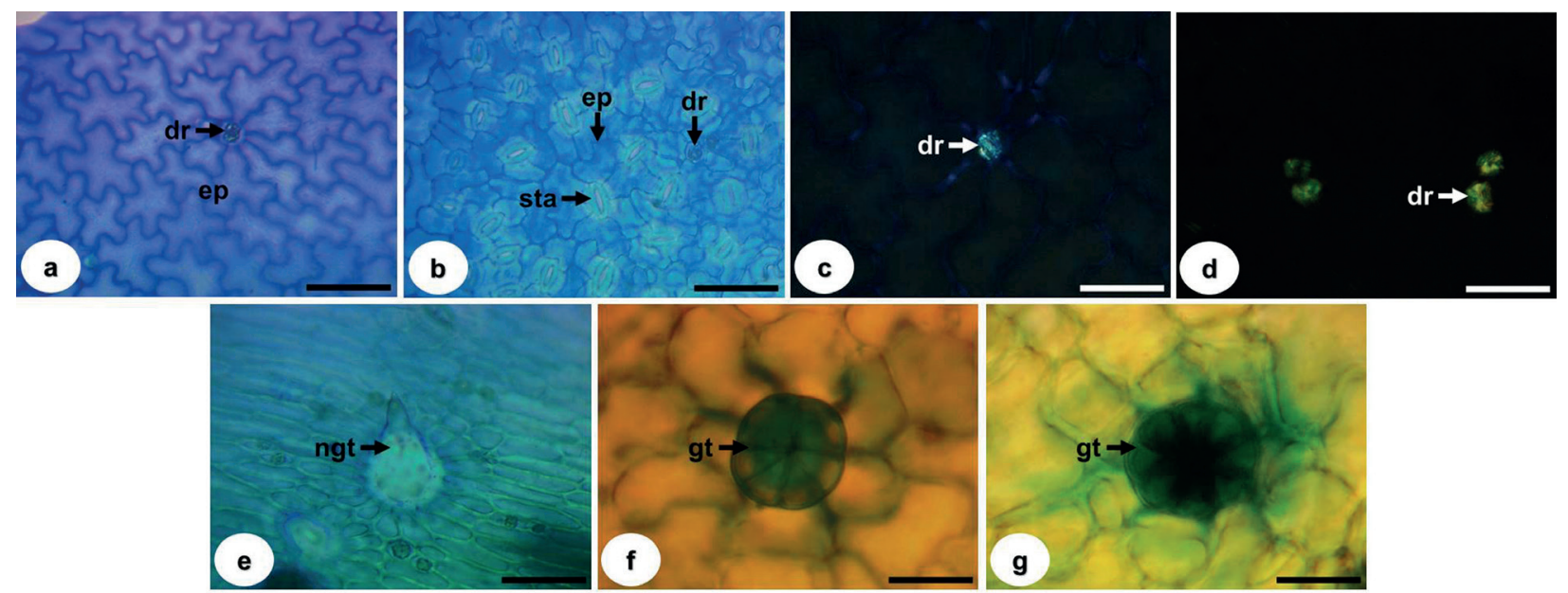

Figure 2 - Paradermal sections of the leaf blade of Artocarpus heterophyllus. a, b, e, f and $\mathbf{g}$ : optical microscopy; $\mathbf{c}$ and $\mathbf{d}$ : polarized light microscopy; a and c: adaxial face; $\mathbf{b}, \mathbf{d}, \mathbf{e}, \mathbf{f}$, and $\mathbf{g}$ : abaxial face. Abbreviations: $\mathrm{dr}=\mathrm{druse}$; ep = epidermis; gt = glandular trichome; ngt $=$ non-glandular trichome; sta $=$ stomata. Bars: $\mathbf{a}, \mathbf{b}$ and $\mathbf{e}=50 \mu \mathrm{m} ; \mathbf{c}, \mathbf{d}, \mathbf{f}$ and $\mathbf{g}=20 \mu \mathrm{m}$.

palisade parenchyma in $A$. altilis (Figure 3i) and of about three layers of palisade parenchyma in $A$. heterophyllus (Figure 3j). The spongy parenchyma consists of several layers of cells loosely arranged (Figure 3i, j). Small vascular bundles are distributed throughout the mesophyll and are protected by an irregular bundle sheath of parenchyma cells. This bundle sheath has extensions that always connect the two epidermal faces in $A$. altilis, which does not occur in A. heterophyllus (Figure 3i, j). Druses are observed in optical and polarized microscopy in the palisade parenchyma and in the bundle sheath (Figure 3k, 1).
Table I shows the main anatomical characters of the two species.

Figure $4 \mathrm{a}$ and $\mathrm{b}$ shows cross-section of the leaf blade of $A$. altilis and Figure $4 \mathrm{c}$ and $\mathrm{d}$ shows crosssection of the leaf blade of $A$. heterophyllus without the addition of reagent. Phenolic compounds were found in the epidermis of A. altilis (Figure 4e) and in epidermis, idioblasts, palisade and spongy parenchyma of $A$. heterophyllus (Figure $4 \mathrm{f}-\mathrm{h}$ ). The presence of tannins was observed in the epidermis of $A$. altilis (Figure 4i) and in the idioblasts and palisade and spongy parenchyma of A. heterophyllus (Figure 4j, k). 

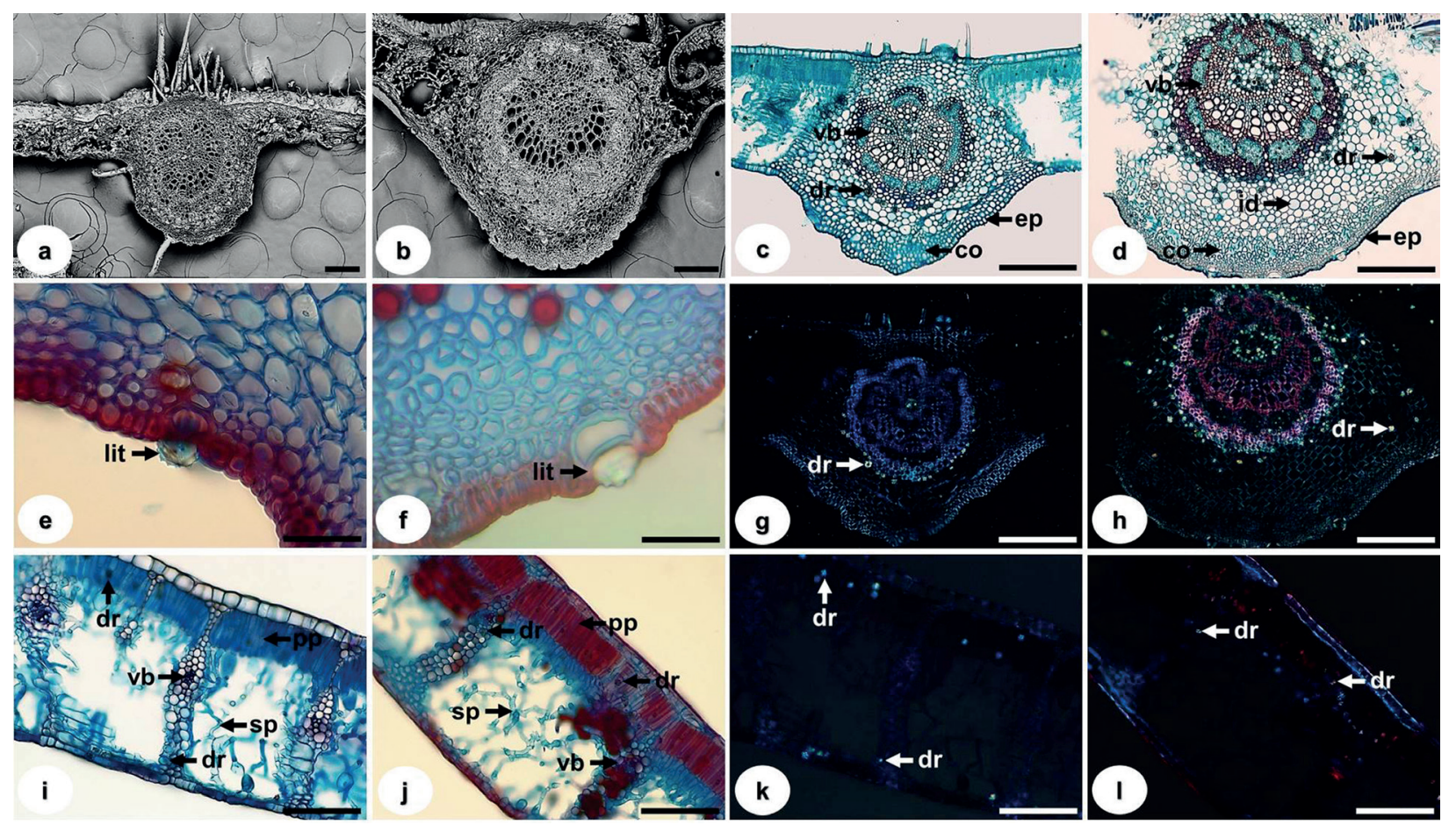

Figure 3 - Cross-sections of the leaf blades of Artocarpus altilis and Artocapus heterophyllus. a, c, e, g, i and k: A. altilis; b, d, f, h, $\mathbf{j}$ and $\mathbf{l}$ : A. heterophyllus; $\mathbf{a}$ and $\mathbf{b}$ : scanning electron microscopy; $\mathbf{c}, \mathbf{d}, \mathbf{e}, \mathbf{f}, \mathbf{i}$ and $\mathbf{j}$ : optical microscopy; $\mathbf{g}, \mathbf{h}, \mathbf{k}$ and $\mathbf{l}=$ polarized light microscopy. Abbreviations: co = collenchyma; dr = druse; ep = epidermis; id = idioblast; lit = lithocyst; $p p=$ palisade parenchyma; $\mathrm{sp}=$ spongy parenchyma; $\mathrm{vb}=$ vascular bundle. Bars: $\mathbf{c}, \mathbf{g}, \mathbf{i}, \mathbf{j}, \mathbf{k}$ and $\mathbf{l}=100 \mu \mathrm{m} ; \mathbf{a}, \mathbf{b}, \mathbf{d}$ and $\mathbf{h}=200 \mu \mathrm{m} ; \mathbf{e}$ and $\mathbf{f}=50 \mu \mathrm{m}$.

TABLE I

Summary of the major anatomical characters of Artocarpus altilis and Artocarpus heterophyllus.

\begin{tabular}{|c|c|c|}
\hline & Artocarpus altilis & Artocarpus heterophyllus \\
\hline Epidermis & $\begin{array}{l}\text { Uniseriate, cells with straight or slightly sinuous } \\
\text { walls on both sides. }\end{array}$ & Uniseriate, cells with sinuous walls on both sides. \\
\hline Stomata & Anomocytic and actinocytic on the abaxial face. & Anomocytic and actinocytic on the abaxial face. \\
\hline \multirow{2}{*}{ Trichomes } & $\begin{array}{l}\text { Adaxial face - non-glandular: simple, hooked and } \\
\text { conical; glandular: multicellular, with eight or more } \\
\text { cells. }\end{array}$ & $\begin{array}{l}\text { Adaxial face - glandular: multicellular, with six or } \\
\text { more cells. }\end{array}$ \\
\hline & $\begin{array}{l}\text { Abaxial face - non-glandular: hooked and conical; } \\
\text { glandular: multicellular, with eight or more cells. }\end{array}$ & $\begin{array}{l}\text { Abaxial face - non-glandular: conical; glandular: } \\
\text { multicellular, with six or more cells. }\end{array}$ \\
\hline Druses & $\begin{array}{l}\text { Epidermis, parenchyma of the midrib, phloem, } \\
\text { palisade parenchyma and bundle sheath. }\end{array}$ & $\begin{array}{l}\text { Epidermis, parenchyma of the midrib, phloem, } \\
\text { palisade parenchyma and bundle sheath. }\end{array}$ \\
\hline Lithocysts & Mainly in the regions of ribs. & Mainly in the regions of ribs. \\
\hline Midrib & Biconvex shape. & Plane-convex to slightly biconvex shape. \\
\hline Collenchyma & Two to four layers. & Three to seven layers. \\
\hline Vascular bundle & Collateral associated with sclerenchyma. & Collateral associated with sclerenchyma. \\
\hline Mesophyll & $\begin{array}{l}\text { Dorsiventral, with one to two layers of palisade } \\
\text { parenchyma and several layers of spongy } \\
\text { parenchyma. }\end{array}$ & $\begin{array}{l}\text { Dorsiventral, with three layers of palisade } \\
\text { parenchyma and several layers of spongy } \\
\text { parenchyma. }\end{array}$ \\
\hline
\end{tabular}




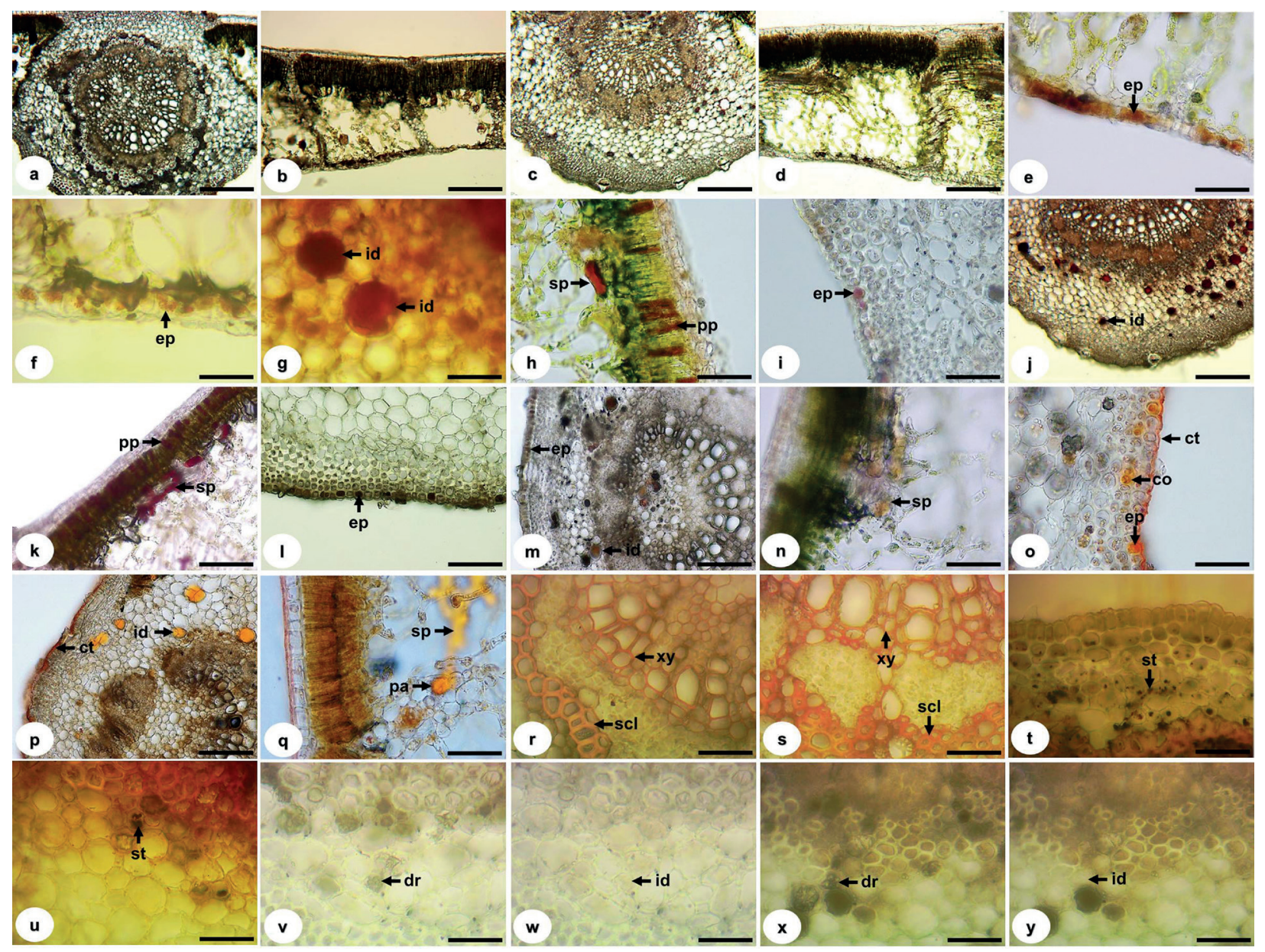

Figure 4 - Histochemistry of the leaf blades of Artocarpus altilis and Artocapus heterophyllus. a, b, e, i, l, o, r, t, v and w: A. altilis; $\mathbf{c}, \mathbf{d}, \mathbf{f}, \mathbf{g}, \mathbf{h}, \mathbf{j}, \mathbf{k}, \mathbf{m}, \mathbf{n}, \mathbf{p}, \mathbf{q}, \mathbf{s}, \mathbf{u}, \mathbf{x}$ and $\mathbf{y}:$ A. heterophyllus; $\mathbf{a}, \mathbf{b}, \mathbf{c}$ and $\mathbf{d}$ : control; $\mathbf{e}, \mathbf{f}, \mathbf{g}$ and $\mathbf{h}$ : potassium dichromate (10\%); i, j and $\mathbf{k}$ : vanillin chloridric; $\mathbf{l}, \mathbf{m}$ and $\mathbf{n}$ : antimony trichloride; $\mathbf{o}, \mathbf{p}$ and $\mathbf{q}$ : Sudan III; $\mathbf{r}$ and $\mathbf{s}$ : phloroglucinol; $\mathbf{t}$ and $\mathbf{u}$ : Lugol; $\mathbf{v}, \mathbf{w}$, $\mathbf{x}$ and $\mathbf{y}$ : hydrochloric acid (10\%). Abbreviations: $c o=$ collenchyma; $\mathrm{ct}=$ cuticle; $\mathrm{dr}=\mathrm{druse}$; ep $=$ epidermis; $\mathrm{id}=\mathrm{idioblast}$; $\mathrm{pa}=$ parenchyma; $\mathrm{pp}=$ palisade parenchyma; $\mathrm{scl}=$ sclerenchyma; $\mathrm{sp}=$ spongy parenchyma; $\mathrm{st}=$ starch; $\mathrm{xy}=\mathrm{xylem} . \mathrm{Bars:} \mathbf{a}, \mathbf{b}, \mathbf{c}, \mathbf{d}$ and $\mathbf{j}=200 \mu \mathrm{m} ; \mathbf{i}, \mathbf{k}, \mathbf{l}, \mathbf{m}$ and $\mathbf{p}=100 \mu \mathrm{m} ; \mathbf{e}, \mathbf{f}, \mathbf{g}, \mathbf{h}, \mathbf{n}, \mathbf{o}, \mathbf{q}, \mathbf{r}, \mathbf{s}, \mathbf{t}, \mathbf{u}, \mathbf{v}, \mathbf{w}, \mathbf{x}$ and $\mathbf{y}=50 \mu \mathrm{m}$.

Triterpenes and steroids were located in the epidermis of $A$. altilis (Figure 41) and in the epidermis, idioblasts and spongy parenchyma of $A$. heterophyllus (Figure $4 \mathrm{~m}, \mathrm{n}$ ). Lipophilic substances were revealed in the cuticle, epidermis and collenchyma of $A$. altilis (Figure 4o) and in cuticle, idioblasts, spongy parenchyma and bundle sheath in the mesophyll of $A$. heterophyllus (Figure $4 p, q)$. In the two species were found lignin in the xylem and sclerenchyma (Figure 4r, s) and starch in the parenchyma (Figure $4 t, u$ ). Figure $4 v$ and $\mathrm{x}$ shows the presence of druses in idioblasts and
Figure $4 \mathrm{w}$ and $\mathrm{y}$ shows the dissolution of the druses with the test of hydrochloric acid (10\%), indicating that they are of calcium oxalate. Tests with Dragendorff's reagent were negative.

Table II shows a summary of the histochemical characterization of the two species.

The chemical microanalyses performed by SEM-EDS in the druses present in the leaf blades of $A$. altilis (Figure 5a-c) and A. heterophyllus (Figure 5d-f) revealed peaks of absorbance for calcium, carbon and oxygen, confirming that they are formed of calcium oxalate. 

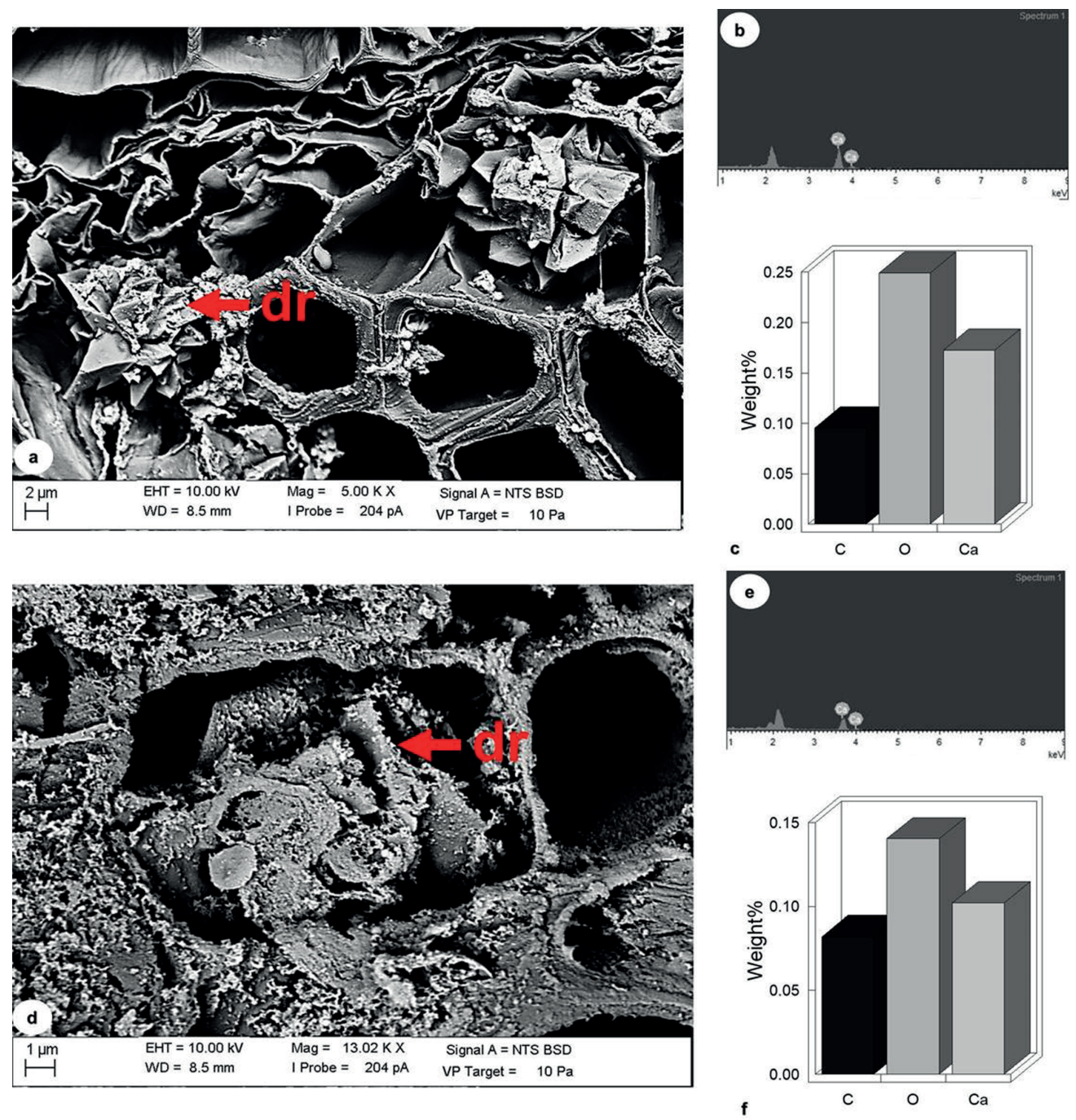

Figure 5 - Scanning electron micrograph and elemental composition of the druses observed in Artocarpus altilis and Artocarpus heterophyllus. a, b and c: A. altilis; d, e and f: A. heterophyllus; $\mathbf{a}$ and $\mathbf{d}$ : druses; b and $\mathbf{e}$ : analysis of elemental composition of the druses; $\mathbf{c}$ and $\mathbf{f}$ : percentage of the chemical constituents of the druses. Abbreviations: $\mathrm{dr}=$ druses.

TABLE II

Summary of the histochemical characterization of Artocarpus altilis and Artocarpus heterophyllus.

\begin{tabular}{lll}
\hline & \multicolumn{1}{c}{ Artocarpus altilis } & \multicolumn{1}{c}{ Artocarpus heterophyllus } \\
\hline Phenolic compounds & Epidermis. & Epidermis, idioblasts, palisade and spongy parenchyma. \\
Tannins & Epidermis. & Idioblasts, palisade and spongy parenchyma. \\
Triterpenes and steroids & Epidermis. & Epidermis, idioblasts and spongy parenchyma. \\
Lipophilic substances & Cuticle, epidermis, and collenchyma. & Cuticle, idioblasts, spongy parenchyma and bundle sheath in \\
& & the mesophyll. \\
Lignin & Xylem and sclerenchyma. & Xylem and sclerenchyma. \\
Starch & Parenchyma. & Parenchyma. \\
Druses & Calcium oxalate. & Calcium oxalate. \\
Alkaloids & Negative. & Negative. \\
\hline
\end{tabular}




\section{DISCUSSION}

According to Metcalfe and Chalk (1950), in the family Moraceae can be found anomocytic and anisocytic stomata. Gangadhara and Inamdar (1977) found anomocytic stomata in both species and actinocytic stomata only in A. altilis.

There are controversies in the literature regarding the types of trichomes found in the two species studied. Martínez (2008) stated that the leaf blade of $A$. heterophyllus is glabrous on the adaxial side. However, in the present study it was found glandular trichome in this face of the leaf blade of A. heterophyllus, as was also found by Gangadhara and Inamdar (1977) and Schnetzler et al. (2017). The types of non-glandular trichomes simple, hooked and conical were also described by Gangadhara and Inamdar (1977) for species of Artocarpus. Studying trichomes of 25 taxa of Urticales, these authors emphasized that the presence of glandular trichomes located in depressions is a diagnostic feature for Artocarpus.

The family Moraceae is known to have cystoliths. Metcalfe and Chalk (1950) stated that true cystoliths occur in Broussonetia, Chlorophora, Conocephalus, Dammaropsis, Fatoua, Ficus, Malaisia, Morus, Poulsenia and Sparattosyce, especially in the epidermis of the leaf. In species of Antiaris, Artocarpus, Broussonetia, Cecropia and Parartocarpus occur structures resembling cystoliths in the hairs.

Periyanayagam and Karthikeyan (2013) and Akinloye et al. (2015) observed druses in the same tissues found in the present study. Wu and KuoHuang (1997) described the presence of prismatic crystals in the bundle sheath of $A$. altilis, which was not observed in this study. These previous studies did not perform histochemical tests and chemical microanalyses to determine the chemical composition of the crystals.

The epidermis of Moraceae species usually consists of a single layer of cells, but may have two to three layers, as in Ficus species (Sonibare et al. 2006). According to Metcalfe and Chalk (1950), there are idioblasts of tannins in the leaf of Artocarpus. However, the present study has demonstrated the presence of other metabolites in idioblasts through histochemistry, such as phenolic compounds triterpenes, steroids and lipophilic substances. Histochemistry was also important to reveal that the two species of Artocarpus present the same types of metabolites, however, located in different tissues. Identification of the chemical composition of the crystals by histochemical test and by SEM-EDS is an important diagnostic feature for genus and species of Moraceae.

Thus, the new information of the chemical microanalyses and the histochemistry, allied to the anatomical description, show the characters of general occurrence in the family Moraceae and of those that allow the differentiation of $A$. altilis and A. heterophyllus.

\section{ACKNOWLEDGMENTS}

The authors are grateful to Coordenação de Aperfeiçoamento de Pessoal de Nível Superior (CAPES) and to Programa Institucional de Bolsas de Iniciação Científica (PIBIC-UFPE)/Conselho Nacional de Desenvolvimento Científico e Tecnológico $(\mathrm{CNPq})$ for financial support in the form of fellowship awards. They also thank CNPq for research funding (409452/016-5).

\section{REFERENCES}

AGRA MF, SILVA KN, BASÍLIO IJLD, FREITAS PF AND BARBOSA-FILHO JM. 2008. Survey of medicinal plants used in the region Northeast of Brazil. Bras J Pharmacogn 18: 472-508.

AGUIAR LCGG AND BARROS RFM. 2012. Plantas medicinais cultivadas em quintais de comunidades rurais no domínio do cerrado piauiense (Município de Demerval Lobão, Piauí, Brasil). Rev Bras P1 Med 14: 419-434.

AKINLOYE AJ, BOROKINI TI, ADENIJI KA AND AKINNUBI FM. 2015. Comparative anatomical studies of Artocarpus altilis (Parkinson) Fosberg and Artocarpus 
communis (J. R. \& G. Forster) in Nigeria. Sci Cold Ari Reg 7: 709-721.

ALBUQUERQUE UP, MEDEIROS PM, ALMEIDA ALS, MONTEIRO JM, LINS NETO EMF, MELO JG AND SANTOS JP. 2007. Medicinal plants of the caatinga (semiarid) vegetation of NE Brazil: A quantitative approach. J Ethnopharmacol 114: 325-354.

BERG CC. 2001. Moreae, Artocarpeae, and Dorstenia (Moraceae). With introductions to the family and Ficus and with additions and corrections to Flora Neotropica Monograph 7, 83 $3^{\text {rd }}$ ed., New York: Flora Neotropica, 346 p.

BRASIL. 2010. Farmacopeia Brasileira, $5^{\mathrm{a}}$ ed., Brasília: Agência Nacional de Vigilância Sanitária, 523 p.

BUKATSCH F. 1972. Bemerkungen zur doppelfärbung Astrablau-Safranin. Mikrokosmos 61: 255.

CHACKREWARTHY S, THABREW MI, WEERASURIYA MKB AND JAYASEKERA S. 2010. Evaluation of the hypoglycemic and hypolipidemic effects of an ethylacetate fraction of Artocarpus heterophyllus (jak) leaves in streptozotocin-induced diabetic rats. Pharmacogn Mag 6: 186-190.

CHANDRIKA UG, WEDAGE WS, WICKRAMASINGHE SMD AND FERNANDO WS. 2006. Hypoglycemic action of the flavonoid fraction of Artocarpus heterophyllus leaf. Afr J Tradit Complement Altern Med 3: 42-50.

FALCÃO MA, CLEMENTE CR, GOMES JBM, CHÁVEZ FLORES WB, SANTIAGO FF AND FREITAS VP. 2001. Fenologia e produtividade da fruta-pão (Artocarpus altilis) e da jaca (A. heterophyllus) na Amazônia Central. Acta Amaz 31: 179-191.

GABE M. 1968. Techniques histologiques. Paris: Masson \& Cie, 1113 p.

GANGADHARA M AND INAMDAR JA. 1977. Trichomes and stomata, and their taxonomic significance in the Urticales. Plant Syst Evol 127: 121-137.

HADDAD A ET AL. 1998. Técnicas básicas de microscopia eletrônica aplicadas às Ciências Biológicas. Rio de Janeiro: Sociedade Brasileira de Microscopia Eletrônica, 179 p.

HAFID AF ET AL. 2017. Antiviral activity of the dichloromethane extracts from Artocarpus heterophyllus leaves against hepatitis C virus. Asian Pac J Trop Biomed 7: 633-639.

JENSEN WA. 1962. Botanical histochemistry: principles and practice. San Francisco: W. H. Freeman, 408 p.

JOHANSEN DA. 1940. Plant microtechnique. New York: McGraw-Hill, 523 p.

KRAUS JE AND ARDUIN M. 1997. Manual básico de métodos em morfologia vegetal. Rio de Janeiro: EDUR, $198 \mathrm{p}$.

KRAUTER D. 1985. Erfahrungen mit Etzolds FSA-Färbung für pflanzenschnitte. Mikrokosmos 74: 231-233.

LIMA JS, OLIVEIRA DM, NASCIMENTO JÚNIOR JE, SILVA-MANN R AND GOMES LJ. 2011. Saberes e uso da flora madeireira por especialistas populares do agreste de Sergipe. Sitientibus Sér Ci Biol 11: 239-253.

LORENZI H, LACERDA MTC AND BACHER LB. 2015. Frutas no Brasil: nativas e exóticas (de consumo in natura). São Paulo: Instituto Plantarum de Estudos da Flora, 768 p.

MACE ME, BELL AA AND STIPANOVIC RD. 1974. Histochemistry and isolation of gossypol and related terpenoids in root of cotton seedlings. Phytopathology 64: 1297-1302.

MACE ME AND HOWELL CR. 1974. Histochemistry and identification of condensed tannin precursor in roots of cotton seedlings. Can J Bot 52: 2423-2426.

MARTÍNEZ AM. 2008. Aportes a la anatomía foliar de Artocarpus communis, A. heterophyllus y Brosimum alicastrum (Moraceae). Revista Jard Bot Nac 28: 201-203.

METCALFE CR AND CHALK L. 1950. Anatomy of the dicotyledons: leaves, stem, and wood in relation to taxonomy with notes on economic uses. Oxford: Clarendon Press, $1500 \mathrm{p}$.

MOZEF T, RISDIAN C, SUKANDAR EY AND SOEMARDJI AA. 2015. Bioactivity of ethyl acetate fraction from the leaves of "Sukun" (Artocarpus altilis (Parkinson) Fosberg) in preventing atherosclerosis. Procedia Chem 16: 106-112.

NWOKOCHA C, PALACIOS J, SIMIRGIOTIS MJ, THOMAS J, NWOKOCHA M, YOUNG L, THOMPSON R, CIFUENTES F, PAREDES A AND DELGODA R. 2017. Aqueous extract from leaf of Artocarpus altilis provides cardio-protection from isoproterenol induced myocardial damage in rats: Negative chronotropic and inotropic effects. J Ethnopharmacol 203: 163-170.

PEREIRA VJ AND KAPLAN MAC. 2013. Artocarpus: um gênero exótico de grande bioatividade. Floresta Ambient 20: 1-15.

PERIYANAYAGAM K AND KARTHIKEYAN V. 2013. Pharmacognostical, SEM and XRF profile of the leaves of Artocarpus heterophyllus Lam. (Moraceae) - a contribution to combat the NTD. Innovare J Life Sci 1: 23-28.

RAGONE D. 2011. Farm and forestry production and marketing for breadfruit (Artocarpus altilis). In: Elevitch CR (Ed), Specialty crops for Pacific Island agroforestry, Holualoa, Hawaii: Permanent Agriculture Resources (PAR), p. 1-18.

RAO GV, GOPALAKRISHNAN M, MADHAVI MSL, MUKHOPADHYAY T, THANUSU J AND EZHILARASI MR. 2013. Dendrite elongation inhibitor from Artocarpus altilis Parkinson. J Pharm Res 7: 358-361.

RODRIGUES E. 2006. Plants and animals utilized as medicines in the Jaú National Park (JNP), Brazilian Amazon Phytother Res 20: 378-391.

ROMANIUC NETO S, CARAUTA JPP, VIANNA FILHO MDM, PEREIRA RAS, RIBEIRO JELS, MACHADO AFP, SANTOS A, PELISSARI G AND PEDERNEIRAS 
LC. 2015. Moraceae in Lista de Espécies da Flora do Brasil. Jardim Botânico do Rio de Janeiro. Disponível em: http://floradobrasil.jbrj.gov.br/jabot/floradobrasil/FB167. (Acesso em 15 Agosto 2017).

ROYER M, HERBETTE G, EPARVIER V, BEAUCHÊNE J, THIBAUT B AND STIEN D. 2010. Secondary metabolites of Bagassa guianensis Aubl. Wood: A study of the chemotaxonomy of the Moraceae family. Phytochemistry 71: 1708-1713.

SASS JE. 1951. Botanical microtechnique. Ames: Iowa State College Press, $391 \mathrm{p}$.

SCHNETZLER BN, TEIXEIRA SP AND MARINHO CR. 2017. Trichomes that secrete substances of a mixed nature in the vegetative and reproductive organs of some species of Moraceae. Acta Bot Brasilica 31: 392-402.
SONIBARE MA, JAYEOLA AA AND EGUNYOMI A. 2006. Comparative leaf anatomy of Ficus Linn. species (Moraceae) from Nigeria. J Appl Sci 6: 3016-3025.

STEVENS PF. 2012. Angiosperm Phylogeny Website. http:// www.mobot.org/MOBOT/research/APweb/. (Accessed on August 15, 2017).

THE PLANT LIST. 2013. Version 1.1. Published on the Internet. http://www.theplantlist.org/. (Accessed on August 15, 2017).

WU CC AND KUO-HUANG LL. 1997. Calcium crystals in the leaves of some species of Moraceae. Bot Bull Acad Sinica 38: 97-104.

YODER LR AND MAHLBERG PG. 1976. Reactions of alkaloid and histochemical indicators in laticifers and specialized parenchyma cells of Catharanthus roseus (Apocynaceae). Am J Bot 63: 1167-1173. 